\title{
Encouraging Girls to Consider a Career in ICT: A Review of Strategies
}

\author{
Iwona Miliszewska and Aidan Moore \\ Victoria University, Melbourne, Victoria, Australia
}

Iwona.Miliszewska@vu.edu.au; Aidan.Moore@vu.edu.au

\section{Executive Summary}

This article reviews strategies designed to improve female participation in ICT studies and careers. In reviewing a range of strategies from around the world, the article identifies the different actors engaging with the "problem" of girls and technology. It points to the many crossovers that occur as governments, higher education providers, industry, and the voluntary sector complement each other in their search for effective solutions to a dilemma that is increasingly recognised as being much more complex than a simple dichotomy of gender and technology. The particular milieu for which this review has been conducted - an educationally and otherwise disadvantaged area of Melbourne, Australia - is reflected in identification of strategies specifically focused on girls and women with low socio-economic status (SES) and students exposed to educational disadvantage.

The first section of this article - an introduction to and overview of the global problem of female under-representation in ICT - provides a context in which the problem, as it exists in Australia, may be understood. Section two consists of four sub-sections in which various types of intervention strategies are described. The sub-sections: Government/Policy-Driven Activity, Education Institutions/Research Activity, Industry Groups, and Voluntary Initiatives indicate the breadth of effort being employed in pursuit of solutions to the "problem" of girls and technology. They point also to considerable overlaps in design, delivery, and results, and illuminate many of the problems encountered along the way. The third and final section of this article discusses the pros and cons of the various types of approach, comparing and contrasting the efforts of government, educational institutions, industry-based groups, and voluntary initiatives in their search for successful and sustainable ways of attracting girls to ICT studies and careers.

This article brings together in one place a variety of strategies aimed at improving female participation in ICT studies. In doing so, it highlights the difficulty of one-size-fits-all approaches and illuminates the importance of front and back-end processes to the delivery of successful programs. It demonstrates that for those designing programs capable of attracting girls to ICT, failing to prepare is preparing to fail.

Material published as part of this publication, either on-line or in print, is copyrighted by the Informing Science Institute. Permission to make digital or paper copy of part or all of these works for personal or classroom use is granted without fee provided that the copies are not made or distributed for profit or commercial advantage AND that copies 1) bear this notice in full and 2) give the full citation on the first page. It is permissible to abstract these works so long as credit is given. To copy in all other cases or to republish or to post on a server or to redistribute to lists requires specific permission and payment of a fee. Contact Publisher@InformingScience.org to request redistribution permission.
Keywords: ICT, girls, educational disadvantage, ethnicity, low SES, international solutions, secondary schools, community-based programs, national initiatives, gender equity.

\section{Introduction}

It is now generally acknowledged by the government, business, employers, and the education and training sectors that 
there is an urgent need for improved targeting of information and advice on ICT studies and careers to students, including high school students, with a particular goal to capturing girls' interest. Despite extensive research and numerous practical interventions designed to address the relative dearth of females in ICT, the problem persists. Evidence from around the world suggests that female predominance in undergraduate enrolments notwithstanding (59\% in Australia, 55\% in America, and greater than 50\% in many European Union countries), girls are reluctant to pursue ICT study at tertiary level (Rees, 2001) accounting for $10 \%$ to $30 \%$ of students in ICT courses and under $20 \%$ of employees in ICT-based careers. The under-representation of females in ICT studies and careers results not only in a massive loss of talent for ICT companies and economies, but also in a technology divide that perpetuates disadvantage among women in general and women of low socio-economic status in particular.

Initial approaches to reverse this trend centered upon notions of equality and affirmative action since the lack of significant numbers of females in the discipline was seen as inequitable. To alleviate the problem, intervention programs aimed at women have promoted information on technology-related careers, provided experience of computing work, and highlighted female role models. Other initiatives focused on helping women develop skills, attitudes, or background knowledge that they were thought to lack. These affirmative action measures, while commendable in fostering gender equality, were not sufficient in that they often served to reinforce the conceptions of ICT as a masculine domain and, consequently, failed to attract women to ICT. This suggests a need for an alternative approach - a re-conceptualization of ICT into an environment that women would naturally embrace. This article seeks to identify the key ingredients of such an environment drawing on lessons learned from a variety of initiatives aimed at attracting to ICT female students in general and female students from educationally disadvantaged back grounds in particular. It has, as its primary focus, a review of strategies deemed successful in attracting girls to ICT studies during their high school years. Whilst the article takes university-generated initiatives into account, it is generally limited to reviewing those activities involving high school girls. The focus is therefore on ways in which the through-flow of female students from high school to university courses may be improved. The article also describes a small number of programs aimed at attracting adult women to ICT. These programs are included for the way in which they illuminate both the complexity of the problem and the potential for community-focused solutions.

\section{Gender-related Issues in ICT Education}

The difficulty to attract and retain female students in ICT, both in Australia and overseas, has been well recognized. The already low number of female students studying ICT in secondary school tends to decrease further at tertiary level. This situation has often been attributed to gender differences in interests, motivation, experience, personality characteristics, abilities, self-efficacy, and socialization. A report recently compiled by the European Schoolnet and CISCO Systems Inc indicated that, of female students across Britain, France, Italy, Poland, and the Netherlands who like studying ICT at high school, most fail to progress those studies to tertiary level or translate their computer competencies into ICT careers (Gras-Velazquez, Joyce \& Debry, 2009). According to the same report, the high drop-out rate can be attributed to "lack of support from role models, persistent stereotyped views that the sector is better suited to men, a lack of understanding about what ICT jobs entail, and in some cases, how easy or difficult they find the subject" (GrasVelazquez et al., 2009, p. 2). Gras-Velazquez et al. perhaps unsurprisingly found a direct correlation between the enthusiasm of mothers for ICT and that evidenced by their daughters. Pleasingly, most mothers surveyed as part of the European Schoolnet-CISCO project were positive about ICT studies. More worrying, however, was the correlation that existed in perceptions about ICT careers, with female role models and the girls they influence believing that jobs in ICT were less likely than other careers to involve travel, helping others, or working independently. As Gras-Velazquez et al. (2009, p. 3) suggest, the "pattern of under-representation of women in ICT 
is set to continue" unless ways are found to educate girls about their rightful place in ICT and unless more is done to support and encourage technically-competent girls to pursue ICT studies and careers.

Far from being restricted to countries covered by the European Schoolnet-Cisco Systems report, attracting and retaining girls in ICT is a global problem with global ramifications. For example, in the Philippines, where ICT has been heralded as a vehicle of social and economic growth for women, a report jointly prepared by WomensHub (Philippines) and the Philippine Legislators' Committee on Population and Development in 2003 argued that whilst new opportunities were opening up to a specific section of that country's female population, "the rapid growth of ICT is also threatening to exacerbate and create new forms of social and economic inequities between men and women; and equally significant among women themselves" (Philippine Legislators' Committee on Population and Development Foundation, Inc., and WomensHub (Philippines), 2003).

This is a phenomenon common to women of ethnic heritage in the United States where in 20002001 , only $19 \%$ of computer science bachelor degrees were awarded to women and only $7 \%$ of the same degrees were awarded to African-Americans and Latinos of either sex (Margolis et al., 2003). The absolute relevance of this figure is illuminated by the fact that in the mid-1980s, American women earned $37 \%$ of undergraduate degrees in computer science ("How to Diversify the Geek Pool", 2000). In this context, Margolis et al. (2003, p. 14) had no hesitation in connecting race, gender and socio-economic status to the "dramatic disparities in opportunities to learn computer science between and within schools" studied as part of research conducted across Digital High Schools "in three quite different communities within the Los Angeles Unified School District."

The extent to which the under-representation of females in ICT is and continues to be a problem in Australia is well documented. "A Fair Chance for All", an Australian Government Discussion Paper released in 1990 set a target of $40 \%$ female representation in non-traditional courses other than engineering by 1995 (Higher Education Council, 1990). Remarking on the way in which under-representation was locking women out of the social and economic benefits of employment "A Fair Chance for All" called upon Australian universities to work towards a resolution of the problem and proposed a range of strategies to be employed. ${ }^{1}$ The Government's concern with improving female participation in non-traditional courses and careers overlapped with its concern for increased participation of students from low-socioeconomic backgrounds, many of whom are, of course, also women. "A Fair Chance for All" also alluded to barrier overlaps where gender and ethnicity intersect. Bringing the three issues together, Margolis et al. and others (Association of Women Educators [AWE], 2006; Butler, 2000; Volman, van Eck, Heemskerk \& Kuiper, 2005) have suggested that the intersection of race, gender, and socio-economic background is critical to low female participation rates in ICT studies and careers.

Data included in "A Fair Chance for All" indicated that in 1988 just under twenty-five per cent of ICT students in Australia were female (Higher Education Council, 1990). Sixteen years later, the situation had failed to improve with female participation in university-level ICT studies stranded

\footnotetext{
${ }^{1}$ Universities were urged to promote non-traditional courses and careers to women and girls; provide bridging courses, especially in mathematics and science; review their curriculums and develop appropriate teaching processes and institute flexible course arrangements. They were also to visit girls in secondary schools and talk to their teachers and parents about education and careers for girls; provide tertiary orientation and experience for girls, their teachers and parents; develop appealing material on courses and careers (for example, material evidencing successful women in non-traditional occupations); take part in local careers events; use the media to publicise courses and provide girls with work experience in science and technology fields.
} 
at twenty-five per cent (AWE, 2006). In 2004, the Association of Women Educators (AWE) suggest, women accounted for just twenty per cent of the 335,600 ICT professionals nationwide (AWE, 2006). Claiming to lead Australia in terms of ICT skills and jobs, the State of Victoria acknowledges through its Multi Media Victoria website that between 2001 and 2007, women in ICT were most heavily concentrated in Sales Assistant roles, where they accounted for seventy per cent of all jobs at that level (Shah, Burke, \& North, 2008).

If a recent Victorian Government report on attitudes to ICT careers and study among 14-19 year olds in that State is accurate, there is still a great deal to be done in terms of promoting ICT. For example, 53\% of (723) students surveyed indicated that they did not know very much about ICT courses at tertiary institutions, and while male students accounted for $61 \%$ of those who had at least some knowledge of what the term "ICT" means, only $35 \%$ of all students surveyed had at least some knowledge of what the term "ICT" means (Department of Innovation, Industry and Regional Development, 2009).

\section{Types of Intervention Strategies}

Given the number of intervention strategies that seek to redress gender inequities in ICT classrooms and places of work, it is desirable to have some system of classification by which those strategies may be discussed. It would, for example, be possible to speak in terms of computer clubs, holiday programs, girl-only classes, role models, etc. We might also speak of whom the various programs target - women of colour, girls of low socio-economic background, ethnic minorities, and so on. Such categorisations are, of course, eminently useful in discussions focused on one particular type of program or one particular type of audience. However, since this project is concerned with an examination of different types of programs and different types of audiences, the schema proposed by Courtney, Timms, Lankshear, and Anderson (2005) in which four types of organisations - government, education institutions, industry-based groups, voluntary groups are identified as being involved in developing and delivering intervention programs, appears most useful. Similarly useful is Courtney et al.'s (2005) suggestion that these organisations can be described as being in the business of policy development, research activity, or practical initiatives. As we shall see, distinctions between what are government, education, industry-based, or voluntary group initiatives are not always clear-cut. Indeed, programs discussed here often evidence overlap between the groups.

\section{Government / Policy-driven Activity}

Policy-driven initiatives are problematic, Helen Jøsok Gansmo (2003) suggests, because schools are often unable or unwilling to satisfy the community expectations they create. In some instances, schools simply reject government directives on the grounds that they "have more important issues to deal with" or on the basis that "they simply cannot follow all...requests from above" (Jøsok Gansmo, 2003, p. 10). Alternatively, schools may cite lack of necessary equipment or personnel, lack of ICT-competent teaching staff or, as Jøsok Gansmo (2003, pp. 10-11) found in her study of government directives aimed at raising female participation in ICT in Norway, schools may claim that not only do students "have better access to and better computers at home", but that they also already have superior ICT skills to their teachers. In addition, it has been argued, schools can operate under perceptions that "digital and gender divides will diminish in due course because of the constant diffusion of the technology in society" (Jøsok Gansmo, 2003, p. 10). Yet again, it may simply be that some school leaderships have a dichotomous understanding of gender in which "computing is seen as important in boys' interests but not to the same extent for girls" (Jøsok Gansmo, 2003, p. 11).

Ironically, Jøsok Gansmo (2003) found, it was what she called "innovative but disobedient" Norwegian schools that proved most successful in raising girls' participation in ICT. At one rural 
school, for example, Jøsok Gansmo (2003, p. 18) found that "lack of funding and the request for flexible teaching systems" resulted in the school using "interactive textbooks on the Internet" that were not only cheaper than conventional books, but also more inclusive of students with different religious, cultural, learning, or other needs. The inclusiveness derived from incorporation of ICT into the general curriculum complements the ethos of the school wherein particular emphasis is placed on establishing positive identity and close ties between students and their community (Jøsok Gansmo, 2003). Whilst the same school was unable to provide each of its 550 students with individual computers, it nevertheless worked to ensure equality of access in other ways, such as establishing an after-hours computer club that gives priority to girls and boys on different days (Jøsok Gansmo, 2003). This school, pseudonymously named Innøy, does not have an intervention strategy aimed specifically at girls. However, Jøsok Gansmo (2003, p. 19) suggests, it brings everyone in the school community along by regarding "computing as panacea for all problems - like heterogeneous groups of pupils, troublemakers, lack of funding and lack of good teachers."

The de facto inclusion of girls, as well as weaker pupils and students with learning difficulties, that derives from incorporating ICT in to the general curriculum and making it a gateway rather than an endpoint has been identified in other Norwegian schools that have disobeyed government directives around gender equity policy (Jøsok Gansmo, 2003). In the case of yet another pseudonymously named school - Innerland - Jøsok Gansmo (2003) discovered that participation in the WISE (Web-based Inquiry Science Environment) ${ }^{2}$ project to teach natural science online and production of an electronic newspaper in English and French for students in Italy and France worked to not only include girls, but also to inspire some students, including girls, to return their focus to school. In common with Innøy, there is at Innerland an emphasis on "learning through technology, rather than teaching the technology itself" (Jøsok Gansmo, 2003, p. 16). Also in common is the emphasis placed on connecting students to their community and giving them positive identities through such things as the school homepage, which has become a model for other schools (Jøsok Gansmo, 2003).

By way of contrast, Faulkner and Stewart (2003, p. 5) observed in their analysis of the "nongender-differentiated" British National Opportunities Fund ICT Training for Teachers and School Librarians (NOF) initiative that, whilst the gender blind nature of policy documentation underpinning that program was "severely at odds with the acute concern expressed in other UK Government departments to encourage more women into ICT based professions and industries," the strategy actually worked in a de facto way towards greater inclusiveness of women in ICT. This de facto effect, which occurred simply because "women outnumber men in teaching", has indirect and long-term potential for bringing about gender changes in the information society in that it positions women teachers as positive ICT role models for the students they teach (Faulkner \& Stewart, 2003, p. 4).

In interviews conducted as part of their research on the NOF initiative, Faulkner and Stewart (2003, p. 17) were surprised to learn that whilst teachers were "aware of the importance of ICTs in the wider world", they had "limited, or at least uneven, awareness about gender and ICT issues as these might be relevant to school children." This gap between the potential for NOF training to effect "gender inclusive change" and the patchy gender awareness that exists in the teaching professions must not be left void, Faulkner and Stewart (2003, p. 5) argue, but must be filled by gender awareness initiatives in which teachers themselves are made "more aware of the extent to which children receive signals about technology and gender" (Faulkner \& Stewart, 2003, p. 5).

\footnotetext{
${ }^{2}$ The web-based inquiry science environment $-\mathrm{a}$ free online science learning environment supported by the National Science Foundation of the United States of America. Students can work on topics such as climate change, recycling, and hybrid-driven automobiles. See http://wise.berkeley.edu/ for full details.
} 
It is certainly too early yet to know if the Digital Education Revolution (DER) (http://www. http://www.DigitalEducationRevolution.gov.au) initiative pursued by the current federal government of Australia will succeed where "A Fair Chance for All" did not. The one-to-one computer to student ratio for Years 9 to 12 students is certainly welcome, as are the deployment of high speed broadband connections to schools, moves to provide new and continuing teachers with access to ICT training and other aspects of the DER. Given the Association of Women Educators' argument that female teachers, particularly those over fifty years of age are struggling to keep abreast of ICT skills at basic and advanced levels, there is certainly much ground to be made up in the area of teacher training alone (AWE, 2006). With Margolis et al. (2003) and others (Association of Women Educators, 2006; Butler, 2000; Volman et al., 2005) identifying the intersection of gender, race, and socio-economic status as critical to the low participation of women in ICT studies and careers, it seems plausible to suggest that interventions aimed at females in that intersection are of particular importance.

\section{Education Institutions / Research Activity}

Claire McCullough (2002) has identified a number of programs across the United States of America in which educational establishments have worked either by themselves or in collaboration with community groups, public institutions, or government agencies to raise female participation in technology related fields of engineering, computer science, mathematics, and physics. As McCullough (2002) suggested, these programs, which are often funded through the National Science Foundation (NSF) Gender Equity Program, vary in size, often call for strong collaboration with local industries, reach out to parents, and frequently involve residential workshops of up to ten days duration. In addition to giving girls identified as being disadvantaged gateways into science and technology careers by providing them with greater access to education in science, mathematics, engineering, and technology, programs such as SECME ${ }^{3}$ RISE (Raising Interest in Science and Engineering) also provide teachers with professional development opportunities around gender equity and the integration of technology into school curricula (McCullough, 2002). In spreading themselves thus, many of the programs have attempted to satisfy various theoretical perspectives found in the literature, such as to the importance of parents as role models, the age at which intervention must occur, the need to raise gender awareness in the classroom and so on.

In her discussion of Girls in the SYSTEM (Sustaining Youth in Science, Technology, Engineering, and Mathematics), McCullough (2002) provided a stunning example of the way in which educational establishments can work collaboratively with community groups to reach disadvantaged members of society and raise their levels of participation in technology related fields. In this instance, several departments from the University of Arizona collaborated with the Sahuaro Girl Scout Council to target Mexican American, Native American, and economically underprivileged girls in the Tucson area. Unlike many other intervention strategies, however, Girls in the SYSTEM opted not to target girls directly, but to multiply its impact by establishing Academies for teachers and Girl Scout leaders who would in turn use the knowledge they gained in gender equity issues and innovative approaches to program delivery to stimulate girls' interest during summer day camps or Girl Scout sessions (McCullough, 2002). By making mini grants available

\footnotetext{
${ }^{3}$ SECME - (Formerly The Southeastern Consortium for Minorities in Engineering) is 'a strategic alliance to renew and strengthen the professional capacity of K-12 educators, motivate and mentor students, and empower parents so that all students can learn and achieve at higher levels.' SECME aims 'To increase the pool of historically under-represented and geographically under-served students who will be prepared to enter and complete post-secondary studies in science, technology, engineering and mathematics (STEM), thus creating a diverse and globally competitive workforce.' See http://www.secme.org/home/index.html for full details.
} 
to parents, teachers and Girl Scout leaders, Girls in the SYSTEM could reach further into disadvantaged communities through the presentations, study groups and mother-daughter STEM (Science, Technology, Engineering, Mathematics) events the grants facilitated (McCullough, 2002).

Unlike Girls in the SYSTEM, which has at its core a train-the-trainer philosophy, Adventures in Computers, Engineering and Space (ACES) has been described as a university-based program that seeks not only to enhance disadvantaged girls' interest in technology related fields, but also to give them opportunities to sample life on a university campus - opportunities that may not have been experienced by any other member of their circle (McCullough, 2002). Again funded by the National Science Foundation Gender Equity Program, ACES sees collaboration between the University of Tennessee Chattanooga (UTC), Girls Incorporated of Chattanooga and the UTC Challenger Learning Centre. Targeting small numbers of girls aged 12 to 14 through residential summer workshops, monthly follow-up activities and technology fairs, ACES attempts, McCullough (2002, p. 8) reported, "to address the "whole person" by including sessions related to nutrition, exercise, crafts, and exposure to positive female role models from the engineering and computer industries."

ACES, McCullough (2002, p. 9) argued, is a program that provides "a unique and considerable variety of approaches... and one that could be replicated elsewhere on a relatively small budget." The budgetary implications of ACES were detailed by Wigal, Alp, McCullough, Smullen, and Winters (2002) when they reported that including camp counselor, activities at the Challenger Learning Centre, food, housing and material, the programs run in the early 2000s cost \$465USD per participant for the camp and $\$ 30$ per participant for the follow up sessions and fairs. Given these costs, it is understandable that by the end of its second year in operation, ACES would, even with generous funding from the National Science Foundation Gender Equity Program, provide access to only 49 girls, half of whom would derive from economically disadvantaged backgrounds (Wigal et al., 2002). In reporting difficulties with getting the balance between instructional and hands on activities right and in pointing to unforeseen problems such as occurred when significant numbers of girls required medication, thus necessitating the engagement of a resident camp nurse, Wigal et al. (2002) also illuminated some of the non-financial challenges posed by individual intervention programs.

Notions of what constitutes a "relatively small budget" may not, of course, be consistent across the globe. The initial 80,000 Canadian Dollars a year funding received by the Centre for Education in Mathematics and Computing at the University of Waterloo in Ontario, Canada, for a program begun there in 2002, whilst seemingly manageable in the Canadian context, would in other situations and places be beyond the realms of possibility (Graham \& Latulipe, 2003). As suggested by Graham and Latulipe's (2003) report on the University of Waterloo initiative, bringing students together from geographically diverse areas for a week-long seminar comes at considerable financial cost. Since the program will be replicated at the University of Calgary from 2010, however, it appears that it has not only been successful in its mission to break down what Graham and Latulipe (2003) identified as the two greatest barriers to female participation in Computer Science - the perception that computer studies are devoid of real world relevance and the perception that computers are for geeks - but that it has also been economically sustainable and worth while.

In the 2002 program, Graham and Latulipe (2003) reported, the number of 14 to 16 year old participants who indicated that they would take Computer Science courses rose from 12 to 22 between pre and post Seminar surveys. Conversely, the number of participants indicating they would not take Computer Science courses fell from 12 to 3. Undoubtedly, these are encouraging statistics, and they were, it would appear, backed up by participant observations that Computer Science jobs seemed much more interesting than previously thought, and by participant acknowledgements that computer scientists are, after all, ordinary people, not geeks (Graham \& Latulipe, 
2003). However, with only 40 girls out of more than 900 applicants being able to take part in the University of Waterloo project, the statistics can be said to have come at what would in many cases be too high a financial cost (Graham \& Latulipe, 2003).

In Brisbane, Australia, for example, financial and other constraints meant that the Queensland University of Technology program go for IT gURL! could initially target only inner suburban schools. The program, which incorporates a range of hands-on activities whilst also exposing girls to "female Faculty staff and students, and female industry professionals", has been deemed a success in that it meets short-term aims of "providing year ten girls with a positive IT experience" and in that it has broken down "some of the myths and stereotypes that...girls might have about the IT profession" (Christie \& Healy, 2004, pp. 37-38). Like many programs of its type, go for IT $g U R L$ ! seeks a domino effect by having participants and their teachers take what they have learned and experienced back to their schools to encourage other girls into ICT studies and careers (Christie \& Healy, 2004).

Whilst its reputation and popularity have in later years seen this program extended to outer suburban schools where, Christie and Healy (2004, p. 36) suggest, "students tended to be less exposed to the different areas of IT", and whilst it has also reached out to regional areas and Indigenous students, go for IT gURL! remains constrained by factors such as finance, staffing, facilities, timing, and the number of girls it can accommodate in its two or three day university-based workshops (Christie \& Healy, 2004). For example, Christie and Healy (2004) explained, there is the issue of when to hold the actual seminar. It must, for practical reasons, occur between university semesters but during school terms. This, of course, narrows the window of opportunity considerably. Moreover, Christie and Healy (2004) suggest, if the timing is inappropriate, as happened in 2001-2002 when the program was planned prior to the six week summer break (December to early February) only to take place in the new school year, enthusiasm quickly dissipates and participation rates drop.

Girls may be daily and "diligent users of IT", Falkenberg Lund and Spanner Witzke (2006, p. 6) have argued, "but they are not aware of mobile phones, chat forums, Internet as more than artifacts and applications. They do not perceive themselves as someone who could potentially work with IT, though that is exactly what they are doing on a low level every day." An initiative developed by the Alexandra Institute at Aarhus University in Denmark has sought to reverse these perceptions through its "Girls and IT" program (Falkenberg Lund \& Spanner Witzke, 2006). Again incorporating a residential component, this time of three days duration and for girls aged 15 to 18 years, "Girls and IT" deliberately focuses on the person rather than the machine. Here, Falkenberg Lund and Spanner Witzke (2006) explain, the emphasis is on bringing girls into contact with positive role models rather than getting them in front of computer screens.

If the Aarhus University-based and Ministry of Science, Technology and Innovation-backed "Girls and IT" initiative appears not uncommon in its approach, perhaps less common, Falkenberg Lund and Spanner Witzke's (2006) work suggests, is the collaborative approach taken by the Department of Computer Science, the School of Architecture, the School of Business and the Engineering College at Aarhus University to develop new Bachelor programs that would complement existing IT courses. In considering the establishment of inter-disciplinary degree courses, Aarhus University appears to extend its support for greater female participation in ICT beyond that observed in many short-term intervention strategies. Providing girls with courses in which IT subjects can be taken alongside other more "interesting" subjects may, through its inclusive approach, convince females "of their central role and importance in the future development and use of IT" (Falkenberg Lund \& Spanner Witzke, 2006, p. 6).

As a program run in British Columbia, Canada by Jenson, de Castell and Bryson (2003) suggests, intervention strategies need not always involve students leaving their schools for a university 
campus or summer camp location. Initiated as part of a wider research project - GenTech (Gender and Technology Research Project) ${ }^{4}$ and structured as a partnership between a school district, researchers and a major computer company, this Canadian program sought to reposition female teachers and students as technology leaders by first training them in the use of new computers and computer software and later having them train male teachers and students (Jenson et al., 2003). It was hoped, Jenson et al. (2003, p. 563) suggested, that "by providing training first to female teachers and students...that the girls and women in the school would regulate the use, climate, and operation of a new computer lab, creating a supportive micro-climate for reconfiguring gender-technology relations" at the school. Consequently, Jenson et al. (2003, p. 569) insist, there occurred a "striking ... increase in girls' enthusiasm for using computers that seemed to correspond to their increase in competence and confidence, both on the computers and off." Over the course of their twelve month project begun in 1996, Jenson et al. (2003, p. 569) observed how "those involved in the project began increasingly to think of and to use computers in new ways." According to these researchers, "Teachers who had used computers simply to teach their students how to type were now using them as an integral part of their curriculum... and gender/technology relations were explicitly addressed and consciously reconfigured" (Jenson et al., 2003, p. 569). Within twelve months of having handed control of the program over to school authorities, however, Jenson et al. (2003, p. 569) observed, "the gender inequalities it had managed to repress had returned, unnoticed and, therefore, quite without opposition or resistance from teachers and students who had been the project's avid participants..."

That their program failed once they handed it over to the school was, Jenson et al. (2003, p. 565) argued, due to a reversal to "a specifically gendered ordering of female students' lives...by themselves, their peers and adults." Jenson et al. (2003, p. 568) were apparently unsurprised that the program failed, since the "intentional reversal of the gendered culture of computer expertise was early on de-legitimated" by a school principal who sought to placate rather than challenge parent, teacher and school administrator accusations of "discrimination" in favour of girls by couching his responses in terms of equity for all. As with most intervention programs, Jenson et al. (2003) suggest, this one ultimately failed to outlast the research project in which it was conceived because the school community failed to address the underlying issue of gender inequity. “...inquiries into the purposes of and justification for a gender equity project in relation to computers within the school were not pursued over the long term by parents, teachers, or administrators, whether involved in the project or not", they argued (Jenson et al., 2003, p. 568).

The connections between schools' commitment to gender equity initiatives and their chances of success that Jenson et al. (2003) alluded to were also made by Deborah Butler (2000, p. 227) when she argued that teachers continue, even unconsciously, to transmit messages "that girls don't need to participate in computer technology." Suggesting that "Teacher education programs remain problematic with regard to the amount of time they spend on examining gender issues in general, much less in technology specifically", Butler (2000, pp. 227-228) insisted "Once girls are excluded, even through very subtle verbal patterns, it is hard for them to reconnect to instruction."

A further problem, as Volman et al. (2005, p.52) see it, and one which is particularly pertinent in times and areas of stretched educational resources, is that teachers are not "very interested in the theme of ICT and diversity in the sense of attention to gender and ethnic differences between pupils", probably because they "have their hands full with introducing ICT itself." Moreover, these researchers argue, there is a tendency for some teachers to undervalue the contribution they can

\footnotetext{
${ }^{4}$ Documents and information regarding the GenTech project may be found at http://www.shecan.com/
} 
make to ICT learning, particularly when they encounter students with greater ICT skills than their own.

The problem of teacher engagement with issues of gender and ethnic differences in classrooms where ICT is present, Heemskerk, Brink, Volman and ten Dam (2005) suggest, is exacerbated by the different ways in which computers are used within and between schools. Whilst "virtually all Western schools have computer and Internet access", they contend, schools "appear to differ in the ways they use these facilities" (Heemskerk et al., 2005, p. 2). "Poor and minority-group students are", it has been argued, "more likely to use computers for drill and practice activities, while their affluent white peers are more likely to use advanced technology tools and/or the Internet" (Heemskerk et al., 2005, p. 2). In situations that Margolis et al. (2003, p. 17) suggest are all too common, teachers and school administrators become fixated on the number and types of computer equipment they have at their disposal, whether the equipment works, whether their school has Internet access, and whether their students "are learning the basic computing skills and becoming technologically proficient." Thus, in their study of high schools in "quite different communities" in Los Angeles, Margolis et al. (2003, p. 17) found that at schools with "the largest number of low-income students of color...few teachers were able to differentiate among "basic computing skills", "computer literacy", and "computer science."

These findings made by Margolis et al. (2003) echoed those in a report on schools in the Fairfax County Public School District in Fairfax County, Virginia (Bennett, Hsi, Lake \& Moore, 2000). Despite being "a technology-rich learning environment" in which internet connection was, even in 2000, available in every classroom frequented by the district's 155,993 students, the only computing related class in which females predominated was word processing (Bennett et al., 2000, p. 46). This statistic was, Bennett et al. (2000) suggested, consistent with national data. Whilst white males enrolled in "artificial intelligence classes at twice the rate of their representation in the school population", African-American girls enrolled in word processing classes at twice their rate of representation in the school population (Bennett et al., 2000, pp. 46-47).

The way in which race, class and gender can intersect to lock females out of ICT careers is also clearly illuminated by 1999 data on those students taking the American Advanced Placement test in computer science (Bennett et al., 2000). Of the 11,793 students across America who took either the "A" or "AB" option in the Advanced Placement test, girls accounted for just $17 \%$ and $9 \%$ respectively. Of those females who took either option, $41 \%$ scored the lowest possible grade (one) on a five point reporting scale. Of the $10 \%$ of all female test takers who identified themselves as being African-American, 83\% scored the lowest possible grade. Whilst the percentage of Hispanic females who scored the lowest possible grade on either test option was, at sixty three per cent, lower than that for African-American women, the enormity of the impact of this statistic for the Hispanic community in America was sheeted home by the fact that only 143 Hispanic females nationwide took either the "A" or "AB" test (Bennett et al., 2000).

Compounding problems arising from intersections of race, gender and class, Heemskerk et al. (2005) suggest, is the fact that computers and computer software are rarely gender or race neutral. Rather, they come pre-loaded with scripts that are all too often male biased and Western-centric. Based on their interpretation of the literature, in which gender or cultural inclusiveness of ICT applications are discussed in terms of content, visual and audio interface, and instructional structure, Heemskerk et al. (2005, pp. 3-4) developed what they termed "an index for the gender inclusiveness and cultural sensitivity of ICT tools." This inclusiveness index was later trialed with 81 students in 4 Dutch schools (Heemskerk, ten Dam, Volman \& Admiraal, 2009). Whilst the study involved girls aged 14-15, its primary focus was not necessarily on race or class. Its finding that girls' learning experiences, attitudes and learning outcomes were especially (but not exclusively) enhanced when using software programs deliberately chosen for their inclusiveness characteristics is nevertheless important. It points, as Heemskerk et al. (2009) suggest, to the need for teach- 
ers to raise their awareness of gender and culture scripts in instructional programs they design or purchase.

Heemskerk et al. (2005) observed a dearth of studies examining how the intersection of gender, race and class works to lock females out of ICT studies and careers. A project undertaken in North Queensland by Neil Anderson (2002) of James Cook University placed particular emphasis on attracting Indigenous Australian females to ICT. Described as an on-going project, "Rural and Remote IT Stars" sought to debunk popular misconceptions around IT careers, "design and deliver innovative workshops and IT camps that would motivate students towards taking up IT careers" and present students "with a wide variety of pathways to IT careers, inclusive of all providers of IT training and tertiary education" (Anderson, 2002, p. 45). Like many intervention strategies mentioned earlier in this review, "Rural and Remote IT Stars" had at its core a threeday residential camp for Year 10 girls. Unlike many of the aforementioned programs, Anderson's was based on the principles of situated learning wherein "Students worked in groups on selfselected areas of interest to explore and use various ICT programs" (Anderson, 2002, p. 45). The involvement of industry professionals gave the camp "a decidedly un-school like experience" and helped establish links between students and industry through which students could obtain work experience in computing related areas (Anderson, 2002, p. 46). Whilst the project was deemed successful in terms of participation and enthusiasm from all involved, student responses to the question "Are you more likely now to choose a job involving computers?" recorded the lowest score of all post-camp survey questions. This, Anderson (2002, p. 47) suggests "illustrates the difficulty of making special projects...effective - the total school and home and social environment needs to support and encourage female students in their use and interest in ICT." Nor can Anderson's (2002, p. 44) observation that university-community partnerships such as that which underpinned his program, often have mixed success, "sometimes failing due to the difficulty of working across different organisational cultures, lack of adequate finance or a variety of other reasons" be easily overlooked.

In coming to understand girls' reluctance to take up ICT studies and careers, a number of researchers have commented on the way in which material presented in those courses fails to capture girls' imagination or play to their inherently strong competencies in writing and expression. In light of this, a Transactional Writing program operated at Miami-Dade Community College and a number of proximate middle schools is particularly interesting (McCullough, 2002). This program's ability to reach out on a class-by-class / school-by-school basis appears to make it much more generally applicable than intervention strategies with residential camps and other resource-intensive components. By appealing to and building on girls' inherently better writing and communication skills, it has been argued, Transactional Writing programs were able to improve the math skills and attitude toward math among all students - male and female - participating in the programs. Of particular interest, however, was the significantly greater improvement in participating girls' attitude toward and skill in mathematics (McCullough, 2002).

That a program should focus first on improving female students' attitudes toward math seems unsurprising in light of Elaine Rich's 5 comment that "Math and problem-solving - that's what it's really about. That's a better predictor at doing good at computer science" than being "able to install the latest software" (Barrios, 2003). With funding provided by the Texas Engineering and Technical Consortium, described by Jennifer Barrios (2003) as "a partnership between higher education and private companies whose goal is to encourage more young people to study science and engineering", Rich initiated First Bytes, a free week-long computer science camp for high school girls at the Austin campus of the University of Texas. If participant feedback reported in

\footnotetext{
${ }^{5}$ Elaine Rich is a senior lecturer in the department of Computer Science at the University of Texas, Austin.
} 
Barrios's (2003) article is any indicator, the program could help reverse a pattern that saw females occupy only 26 of the 233 computer science places at the University of Texas, Austin, in 2003. One student reportedly found her interest in computing greatly aroused when she learned that it might be "used to design an artificial heart" (Barrios, 2003). Others said that whilst their career choices had not been altered by participation in the First Bytes program, they would nevertheless give much greater consideration to taking Computer Science as a minor stream in degree courses. However, as an associate professor in the computer sciences department at the University of Texas observed, whilst getting 50 girls at a time interested in computer science through the First Bytes program was a start, such small-scale interventions were unlikely to change society (Barrios, 2003).

Recognizing the limitations of small-scale, camp style intervention programs, researchers at Deakin University, Australia, (Geelong Campus) augmented their own holiday program for twenty Year 10 girls with a video they hoped would be widely taken up by Australian schools (Teague \& Clarke, 1993). Considered "highly successful in terms of...immediate responses received" these very different but complementary initiatives shared common goals: breaking down negative stereotypes in which computer-related work is viewed as antisocial and isolating, and demonstrating the variety, challenge and people-oriented nature of computing (Teague \& Clarke, 1993, p. 208). Armed with schoolgirls' analyses of existing videos in which educational institutions and computer industries were the primary focus, and armed too with information gleaned from schoolgirls about their future career preferences, Teague and Clarke constructed a video in which professional women shared insights into their lives as computing professionals and demonstrated the ways in which the future career preferences of a great many girls could be satisfied through computing occupations. Despite positive responses received at the time from students, teachers, academics and computing practitioners (Teague \& Clarke, 1993), Clarke (now researching as Valerie A. Scott) acknowledged several years later that there remained "marked gender differences in the proportions of girls and boys who elect to take Victorian Certificate of Education studies in computing and who elect to study Computer Science at the tertiary level" (Scott, 1998, p. 17). If the low production and distribution costs associated with the video and an accompanying booklet had potential to trigger a paradigm shift among Australian female students, their teachers and significant others, Craig's (2009) finding that by 2007 not only were there fewer students of computing in Australia generally, but that of the reduced pool, less than $19 \%$ of those studying IT at undergraduate level were female, confirms that such a shift has not occurred.

More successful, it would appear, was the committee-driven Women in Computing initiative at Central Queensland University (CQU) where establishment of links with secondary schools, distribution of career information packs, bridging programs for women without previous computing experience, gender and learner awareness sessions for university staff, establishment of networks to support women students and workshops to improve graduates' interview and job seeking skills saw female enrollments in the Bachelor of Information Technology rise from 13\% in 1992 to $24 \%$ in 2001 (Clayton \& Lynch, 2002). Successful though it was, Women in Computing was apparently not without its critics (Clayton \& Lynch, 2002). There was, Clayton and Lynch (2002, p. 90) suggest, significant hostility towards it "amongst some staff and students, including women students" who, though appreciative of the efforts being made, nevertheless baulked at having attention drawn to them as a gender group.

Whilst Women in Computing overcame these difficulties by taking a more subtle approach to supporting women as part of a program to support all students, its fate was ultimately sealed by circumstances beyond its control (Clayton \& Lynch, 2002). In what was a classic example of the way in which even successful intervention strategies can be undone by changes internal to their place of conception or operation, Women in Computing fell foul of departmental amalgamations at CQU that not only resulted in Computing being incorporated under the general rubric of Sci- 
ence, thereby disguising the under-representation of women in Computing, but also and consequently resulted in a loss of financial resources (Clayton \& Lynch, 2002). It was, too, a classic example of the way in which shifts in direction at governmental levels can adversely impact on women and other disadvantaged groups in society, since with the change of Federal Government that occurred in Australia in 1996 there came a reorientation of policy and finances "away from women in non-traditional areas to, for example, people with a disability and people from nonEnglish speaking backgrounds" (Clayton \& Lynch, 2002, p. 91). The consequent loss of funding that this shift in government focus entailed made retention of a Women in Computing coordinator's position unsustainable (Clayton \& Lynch, 2002). Whilst loss of funding for the coordinator position did not by itself fatally wound the program, it nevertheless contributed to its demise by, for example, transferring duties to program supporters whose roles were already over demanding.

It is, as Clayton and Lynch (2002, p. 90) suggest, difficult to understand why such "a successful program was disbanded, when participation rates were still below that specified by the Federal government." Yet it is a reminder of how vulnerable even successful programs are to the winds of change. Margolis et al. (2003) similarly remarked on this when they recounted how a Los Angeles school whose student population was $98 \%$ Latino was forced to divert funds away from computing classes because the school had been declared a "low performing school" by educational authorities on account of seemingly poor test results in subjects other than computing.

Whilst the literature is replete with examples of university-based intervention strategies, there is a dearth of evidence surrounding initiatives originating in pre-tertiary places of learning. This is not to suggest that such initiatives are not being made. Rather, it is an observation that whilst high schools, for example, may be developing their own strategies, they are not presenting or promoting them as frequently or as widely as they might. An exception to this is material published by Frank Lanzer (2009), a former public high school teacher and now Associate Professor and Chair of Engineering and Technology at Anne Arundel Community College in Arnold, Maryland, USA. Whilst teaching at Chesapeake High School in Pasadena, Maryland, Lanzer (2009) responded to girls' abysmally low rates of participation in computer science and information technology programs by initiating low-cost technology camps for all rising ninth grade girls. The success of Lanzer's initiative is borne out by its longevity - technology camps have been running each year since 2002 - and by its expansion to the local community college (Lanzer, 2009). Whilst Lanzer's summer technology camps initially failed to attract as many girls as hoped, enrollments were quick to pick up in subsequent years so that "By the third year, two separate camps were run with a combined enrollment of fifty-six girls" (Lanzer, 2009, p. 3).

The summer camps run for students of Chesapeake High School and Anne Arundel Community College are, Lanzer (2009, p. 7) contends, "a demonstration of reaching girls and minority students before they reach a critical time of their lives, when peer pressure drives so many to lose self-confidence and "swallow their voices." Whilst Lanzer $(2009$, p. 7$)$ does not provide us with evidence as to whether his technology camps have resulted in greater female enrollments in computer science and/or information technology programs at Chesapeake High School or Anne Arundel Community College - other than to say that students "appear to be more motivated to pursue their goals" - he nevertheless provides a salient example of the way in which interventions of this nature often rely on individual actors. His account of the way in which a concerted effort to improve female enrollments in computer science through "informative presentations ... highlighting opportunities to gain new and interesting skills" failed, reminds us, moreover, that schools are concerned about these issues, but that they sometimes need assistance in translating that concern into effective action (Lanzer, 2009, p. 2). It reminds us, too, that coming up with new approaches and putting them into action can be all too often left to individuals.

The onus of responsibility that falls on the shoulders of individual teachers is well illustrated in research undertaken by Fisher, Lang, Craig, Forgasz, and Lazarenko (2007). In a survey of 280 
schools across Australia, Fisher et al. (2007) found that only 12 had implemented any kind of intervention strategy to address gender inequities in information technology classrooms. Of the twelve schools that had put intervention strategies in place, most opted for computer clubs, which were, Fisher et al. (2007, p.5) argued, run in an ad hoc way and heavily reliant on the "time, enthusiasm and dedication of a single individual." In the case of one school with 1300 students and 90 staff, not only did organization and running of the computer club fall to one individual, but that teacher had also personally funded the program (Fisher et al., 2007).

Despite this uncoordinated approach and over-reliance on individual efforts, it would appear that computer clubs have enjoyed widespread success in getting girls interested and enthusiastic about IT (Fisher et al., 2007). Organizers reported rapid increases in girls' confidence and skills with IT, a greater inclination to experiment with the workings of computers and increases in the number of girls choosing IT subjects. In one case, Fisher et al. (2007) reported, the number of club applicants exceeded the number of places available, even though there was a dollar cost associated with membership. That clubs have not been even more successful, Fisher et al. (2007) suggest, is due to constraints such as lack of resources, including financial resources, difficulties in organizing suitable activities, scheduling problems, low-level computing skills and confidence among participating teachers, and frequent inadequate support from within the schools in which the initiatives have been generated.

\section{Industry-based Groups}

CC4G (Computer Clubs for Girls), a nationally coordinated initiative of the not-for-profit, employer-led organization e-skills UK has, since its launch in 2005, reached into more than 3600 schools across England, accumulating on its way in excess of 125,000 members (http://www.eskills.com/e-skills-UK-in-schools/1166). By comparison with intervention strategies mentioned earlier in this report, most of which accommodate less than 50 girls at a time, the reach of CC4G is nothing short of astonishing. Just how popular and far-reaching is this program that offers "more than 80 hours in e-learning and 170 hours of offline projects and challenges to participating schools" with courseware that is "mapped to the English ICT curriculum" can be seen in a July 2008 report published by e-skills UK (Lang, Fisher \& Craig, 2007, p. 11; Steele, 2008). There it is reported that $62 \%$ of members surveyed "said that CC4G had made them more likely to want to work in a career involving technology" (Steele, 2008). In the same report, 98\% of surveyed club facilitators agreed that membership of CC4G would have "a positive impact on members" achievements at KS2/3 in IT (Steele, 2008). Moreover, of those schools who participated in surveys for the July 2008 report, $98 \%$ said they would continue to run CC4G for the next school year.

Writing in Computer Weekly in August 2007, Rebecca Thomson cited the head of IT at one English school as saying that "the number of girls studying IT GCSE at her college had trebled in five years." Having incorporated CC4G into the curriculum, the teacher in question remarked "I think $\mathrm{CC} 4 \mathrm{G}$ does make more girls consider IT as a career because it makes it seem more fun. And because it is so fun for them, they are learning and thinking about IT without realizing it" (Thomson, 2007). Whilst these remarks and the e-skills UK report suggest CC4G is an enormously popular strategy with national backing and roll-out, it may yet be too early to know whether it will result in substantially greater numbers of English girls pursuing higher level computer related studies, or ICT careers. This point was stressed by Jayne Miles, IT infrastructure manager for Ford UK whom Thomson (2007) quoted as saying "The proof is still a few years away, because we need to see how many girls will actually go on to study at university and go into the profession..."

Whether CC4G will develop into a panacea for what is a global problem remains to be seen. Whilst we cannot extrapolate too far on the basis of one study, Lang, Fisher and Craig's (2007) 
report on their attempt to transfer the $\mathrm{CC} 4 \mathrm{G}$ concept to an Australian context is nevertheless useful and illuminating. Using unedited CC4G materials, Lang et al. established a weekly lunchtime club for girls at Brentwood Secondary College in Melbourne, initially enrolling 27 Year 7 students. Whilst CC4G appears to work well in England and other parts of Britain, Lang et al. (2007) found it less applicable in an Australian context where lunchtime clubs enjoy little tradition or popularity. Indeed, Lang et al. (2007, p. 11) reported, the initial 27 enrollees dwindled to just 5 by week four of the program and, with most participating students coming from one home room group, there was a suspicion that the club was not accepted "by other form groups and year levels." If the program run at Brentwood Secondary College had minimal impact in the recommended lunchtime format, the positive reception it got from the school principal, IT manager, the participating IT teacher, pupil facilitators and students who reported liking the materials and experiences if not the timing, suggested that, with some modifications to suit the local environment, mapping to Australian school curricula and making the club an elective subject, the CC4G model could be successful (Lang et al., 2007).

However, as Bennett et al. (2000) argued, there is a fundamental risk attached to the "club" concept. There is, they argued, the danger of computer clubs becoming venues for "bright white boys" (Bennett et al., 2000, p. 53) Unless tightly controlled, they suggest, these voluntary spaces that are so crucial to giving many students time on computers they might not otherwise have, and which provide opportunities for some of the most intensive learning to take place, can become venues in which gender and racial differences quickly exceed and exaggerate those that exist in classrooms. In what points to many of the difficulties surrounding computer clubs, Bennett et al. $(2000$, p. 53) noted that "To ensure equitable participation in such environments, educators and administrators need to avoid social arrangements and educational practices that isolate girls who want to use computers or that allow one group of students to so dominate the setting that others find working there awkward or unwelcoming." Moreover, they argued, "...educators need to compensate for the disparity between boys and girls, rich and poor, and heavy to little prior experience with technology, when establishing clubs and extracurricular activities."

In surveys conducted for a European Schoolnet-CISCO Systems report on women and ICT in five European countries - Italy, Poland, UK, Netherlands, France - it was found that with the exception of the Netherlands, more than $50 \%$ of students are influenced by role models (GrasVelazquez et al., 2009). Whilst parents, female teachers and female relatives figured prominently amongst those nominated as role models, so too did celebrities. This nomination of celebrities as significant role models was incorporated into the highly innovative British initiative, ITBeat, which aims to disabuse 11-15 year old girls of negative perceptions about IT by overlaying technology with a sense of glamour (Pitt, 2003). In order to do this, ITBeat, which was conceived in 2002 as part of the e-skills UK three year Image Impact Program to improve IT's poor image, brings "the world of pop and celebrities directly into the young girls' field of IT vision" (Pitt, 2003, p. 3).

In partnership with teenage magazine $J-17$ and the pop music industry, ITBeat had at its core a competition for teenage girls in which they designed a website for their favourite pop star. Finalists in the competition would then be "invited to a celebrity event in central London, with the opportunity to meet their pop idols" (Pitt, 2003, p. 9). According to Pitt, (2003, p. 9) the ITBeat initiative incorporated "a very strong gendering process, whereby the awareness of being a girl was used as a tool for empowerment." Throughout the competition phase and on into the London event phase, participants were "exposed to female role models who work in some of the most glamorous and exciting areas of IT, in order to show how the skills young girls already possess could give them access to exciting, well-paid careers in IT" (Pitt, 2003, p. 10). "Although giving greater consideration to the target audience or the users of any strategy" - in the way that ITBeat 
did when it took account of the lifestyles and aspirations of teenage girls -"may seem like an obvious prerequisite for its success", Pitt (2003, p. 12) argued, "policy makers often fail to do so."

The ITBeat program clearly had potential to satisfy calls in the literature for strategies aimed at making ICT relevant to girls and women. It could additionally address calls in the literature for greater use of role modelling. Its "user-centric approach to design" also suggests it could be easily transferred to other countries, resulting in a) improved skill levels and b) an improved image for ICT (Pitt, 2003, p. 3). Whilst it would, as Pitt (2003) suggests, be difficult to measure the program's success in absolute terms, its potential to initially attract the attention of young girls should not be underestimated. However, in so far as Pitt (2003) was concerned, the program's greatest strength lay in its ability to conceptualise the user at the centre of the initiative - something policy makers are frequently incapable of doing. Regrettably, an Internet search failed to confirm that ITBeat is still in operation.

\section{Voluntary Initiatives}

In her paper on the community-based Women's Electronic Village Hall (WEVH) initiative in Manchester, England, Martha Walker (2005) identified numerous reasons for the emergence of voluntary organizations seeking to give women gateways into ICT studies and careers. She argued that despite 20 years of debate, schools continue to "reproduce and legitimize dominant gender-science relationships programming boys and girls for clearly defined roles", universities continue to entice women into computing courses that are not designed with them in mind, and workplaces continue to use women's "sexuality and/or femininity" to undermine them when their knowledge and skills threaten what remains a bastion of male dominance (Walker, 2005, p. 13). "This lack of change is", Walker (2005, p. 13) argued "also evident in a more covert way where gendered meanings are inscribed in the technology itself."

Arguing that "women-only ICT provision is still very much needed", Walker (2005, p. 13) described the Odyssey project at WEVH as one in which "learning specific work related skills" has been sidelined by the simultaneous development of multimedia and personal development skills, from which participating women produce multimedia personal profiles. According to Walker (2005, p. 13), the skills and knowledge women gain through this form of learning not only enables them to challenge gender-technology relations, but also, through the change it brings about in their own lives, enables these women to "inspire change in their communities and society in general."

Based on interviews with staff and participants at WEVH, Walker (2005) concluded that courses there responded to the needs and interests of women and brought about changes in attitude towards technology by giving participants a realization that their lack of confidence stemmed not from an inability to understand, but from a lack of accessible information. Whilst this program was aimed at adult women, the issues Walker raised resonate in literature concerning ICT instruction in high school and tertiary educational settings.

Begun in 1992 with around two hundred participants, The Gathering is a Norwegian computer party that seeks to give "young people... a common place where they could meet, learn, socialize and exchange ideas and knowledge about computers" (Nordli, 2003, p. 8). Now attracting crowds in excess of four thousand people with average ages between 17 and 23 years, The Gathering remains male dominated but has managed to grow female participation rates to ten per cent. This growth in female participation, whilst ostensibly small, must nevertheless be viewed against the fact that in its first year of operation The Gathering attracted only two females (Nordli, 2003). Whilst public reaction was initially influenced through negative media reports in which attendees were portrayed as geeks avoiding the sun in favour of spending their time in front of computer screens, that has changed to the extent that by 2002 the party was officially opened by Norway's 
Minister of Trade and Industry. Interestingly, efforts to increase female participation through free or reduced admission costs failed, but when full price admission for girls and women was reintroduced, "the amount of female participants increased substantially" (Nordli, 2003, p. 19). These days, Nordli suggests, females are to be found at all levels of the KANDU (Kreative Aktiv Norsk Data Ungdom / creative and active Norwegian computer youngsters) voluntary organization that stages the parties. Whilst they may operate according to a hacker ethos of "same rules for everybody", Nordli (2003, p. 20) argues, party organizers nevertheless bend the rules to pursue their agenda of inclusion. The party organizers continue to struggle with the gendertechnology problem, but they use every opportunity to showcase girls' skills in ways that draw attention to the girls as computer enthusiasts rather than girls (Nordli, 2003).

As mentioned earlier in this report, collaboration among and between various actors is not at all uncommon where intervention strategies aimed at increasing female participation in ICT studies and careers is concerned. Two examples should suffice. The Ardmore Network of Community Resource Centres on the Scottish Hebrides, though a government initiative, nevertheless depended, in part, at least, upon the commitment of volunteer computer enthusiasts in the communities in which it operated (Faulkner \& Kleif, 2003). Whilst bridging digital divides associated with remote and rural areas was the primary goal of the Ardmore network, it nevertheless worked, Faulkner and Kleif (2003) found, in a de facto way to include more women than men. That this was so, it has been argued, was a consequence of the fact that Community Support Workers involved in the program were all women (Faulkner \& Kleif, 2003). Though not ICT experts, these women were effective and trusted bridge builders between women and technology, largely, it would appear, because they were able to "demonstrate in their interactions with users, that you can work things out with ICT if you're willing to experiment" (Faulkner \& Kleif, 2003, p. 11).

It would appear that the Ardmore Network was particularly successful in building networks of expertise and in promoting the kind of informal learning adjudged such an important complement to formal learning (Faulkner \& Kleif, 2003). In one remote village, for example, a single street could boast of several local experts where previously there had existed not even a single computer. According to the Community Support Worker in that area, computer ownership and usage had surged, covers were constantly being removed from computers to add or exchange parts, old computers were constantly being re-cycled to bring new users into the digital sphere and there had been a consequent "snowball effect on the general level of technical knowledge..." (Faulkner \& Kleif, 2003, p. 12)

Analysis of the Ardmore Network provided by Faulkner and Kleif (2003) is particularly illuminating in that it turns the problem of gender and technology on its head. By examining reasons behind poor male participation rates in courses run through the Network, these researchers were able to demonstrate how important meeting audience needs is to the success of any program or course. Ostensibly, it appeared, men were less engaged with the project because they lacked appropriate role models - all the Community Resource Workers were female - and because they were less comfortable with the female-dominated learning environments (Faulkner \& Kleif, 2003). Digging a little deeper, however, Faulkner and Kleif (2003) found a range of factors other than gender at play. Types of occupation, whether or not men dominated computer access at home and the degree to which men were competent users of ICT were in fact, Faulkner and Kleif (2003) suggested, as likely as gender to determine the make-up of user groups. Age, interest in ICTs and unwillingness to reveal their lack of knowledge about ICT were also contributing factors. All of this, Faulkner and Kleif (2003) argue, points to the fact that not only are one-size-fitsall strategies likely to exclude many of those they seek to attract, but also that relationships to ICT are much more complex and diverse than gender-based arguments suggest.

The Amsterdam Westerpark Computers and the Internet program rolled out in 2001 as part of a national initiative to bridge digital divides associated with lack of access to ICTs is yet another 
example of a non-gender specific program that has been de facto much more inclusive of women than men (Rommes, 2003). With finance from the national government and collaboration between community organizations, foundations and companies, and with the assistance of volunteer teachers and computer experts, the Amsterdam Westerpark project enrolled almost 500 people in its first two years of operation (Rommes, 2003). Whilst its focus was primarily on closing digital divides associated with computer ownership or lack thereof, and on bringing ethnically diverse communities in the Westerpark area of Amsterdam closer together through the use of public access computers, the project was nevertheless remarkable for the fact that it attracted almost three times as many women as men (Rommes, 2003). It is unclear whether the $70 \%$ inclusion rate for women was replicated across the other 233 local projects initiated as part of the national "digitale trapvelden" plan, however the figures cited by Schoutendorp, van den Steenhoven, and Lenos (2002) and reproduced by Rommes (2003) suggest that this might have been the case. Of the 234 projects, Rommes (2003, p. 8) reported, roughly $65 \%$ were aimed at children, $45 \%$ aimed at teenage boys, roughly the same number targeted "people from Turkey, Morocco or Surinam, $40 \%$ aimed at teenage girls, $40 \%$ aimed at elderly people and...20\% aimed, amongst others, at women." Whether other programs were successful, deliberately or otherwise, in attracting more women than men likely depended on whether they met the needs of that audience. Whilst course timing and the provision of day care facilities for children were obviously important, Rommes (2003) suggests, the provision of female only courses proved crucial in attracting women from some ethnic groups. Similarly important, it appears, was the decision to explain the relevance of ICT to the lives of young women and girls in particular and the inclusion of language teachers whose job it was to help the women with language problems (Rommes, 2003).

Whilst the Amsterdam Westerpark project, and possibly many more of the 234 local initiatives begun under the Dutch "digitale trapvelden" plan, proved successful in attracting significantly greater numbers of women than men, Rommes (2003) suggested, it was not quite so successful in raising their ICT participation rates or their use of the Internet. Nor, it would appear, was the program as successful as had been hoped in its community building endeavours. The explanation for this, she argues, lay in the program organisers' decision to prioritise the technology rather than the people using it. That is, program organisers opted for courses in which attempts were made to give participants "an overview of everything that is possible with a computer", rather than designing courses that were less complicated but given to building networks of learners capable of learning from each other (Rommes, 2003, p. 14).

This suggestion that efforts to raise female participation rates in ICT studies (and, consequently in careers) should be person-centered rather than technology-focused echoes in the recent Victorian (Australia) Government report on "Attitudes to ICT careers and study among 14 to 19 year old Victorians", wherein students "presented with a range of options to promote ICT careers to young people ... nominated work placements or job experience with ICT companies" as the most effective methods, followed by scholarships, the opportunity to explore emerging technologies through expos and opportunities to speak with already engaged in ICT careers (Department of Innovation, Industry and Regional Development, 2009).

\section{Discussion}

This review of intervention strategies highlights differences and similarities in the way different actors perceive the problem of girls and ICT. For some, the problem is one of image, wherein negative stereotypes, myths and misconceptions have been allowed to build up around the role of computers in society and about the people who inhabit the world of computing. Nordli's (2003) observations about Norwegian computer parties (The Gathering) suggest that the media have played none-too-small a role in producing negative stereotypes of computing professionals as anti-social geeks devoid of personality or diversity of interests. Others perceive the girls and 
technology problem as one which is institutionally based. They point to the way in which schools and their teachers fail to accord girls and boys the same natural affinity with computers, the way in which negative messages about girls and technology are transmitted, consciously or unconsciously, the general lack of interest in ICT pervading some schools, and the way in which computers are used differently within and between schools as reasons behind unequal representation of males and females in ICT studies and careers, and as reasons behind socio-economic and ethnic/racial disparities in representation in ICT (Butler, 2000; Heemskerk et al., 2005; Jenson et al., 2003; Margolis et al., 2003; Volman et al., 2005). Another commonly cited explanation for the paucity of female ICT students and professionals is the technology itself. Heemskerk et al. (2005) and Heemskerk et al. (2009), for example, point to the way in which computer software, interfaces and learning structures come pre-loaded with gender scripts that have an obvious male bias, thus excluding girls from engaging with or being interested in the technology itself. Walker (2005) has also commented on the role of gender scripts in turning girls off computing, but for her the overarching problem appears to be of a systemic nature, wherein schools, places of higher education and training and places of employment mutually reinforce negative connotations about girls/women and computing.

The way in which the problem of poor female representation in ICT studies and careers is perceived determines the responses made to the problem. As demonstrated in our review, policydriven initiatives can be problematic, in that they can be chaotically received and acted upon, and in that they are vulnerable to shifts in emphasis resulting from changes in government direction or institutional requirements. Where they have been shown to work in "de facto" ways, such as happened with the British Government initiative to provide all teachers and school librarians with ICT training, policy-driven initiatives are nevertheless capable of leaving gaps that can only be filled by more policy or organically produced intervention programs. The difficulty, as Faulkner and Stewart (2003) remind us, is that filling the gap frequently becomes a matter of chance.

As a consequence of the gaps Faulkner and Stewart (2003) alluded to and the concern that a great number of researchers share about the problem, there has arisen in places of higher learning a strong tradition of investigation into the under-representation of girls and women in ICT studies and careers. As can be discerned from the foregoing review, the intervention strategies that university researchers produce are underpinned by one or more theoretical perspective. They might, for example, seek to target girls at a particular age, work on dispelling myths and negative stereotypes built up around ICT, or seek to appeal to girls' interests and aspirations. Frequently, it can be seen, they seek to cover as many theoretical perspectives as possible. Such programs are often successful, as demonstrated by their longevity and popularity. However, they are also vulnerable to weaknesses. Most notably, they are constrained by resources, financial and otherwise; are usually small in scale; are heavily dependent on the goodwill and cooperation of schools in a particular locale and, it has been argued, address the symptoms but not the underlying causes of the girls and ICT "problem". In addition, university-based or produced initiatives can, if not managed correctly, be divisive, technology rather than person centred, overly reliant on multiplier effects and, most worryingly, according to some researchers, unsustainable beyond the life of the research project from whence they sprang.

These drawbacks notwithstanding, programs originating at university research levels appear to have potentially greater reach into the communities in which they operate than top-down, onesize-fits-all approaches. They have, for example, the capacity to target particular groups, such as students of low socio economic status. They can, by taking account of research on the need for more inclusive computer software, be tailored to meet the needs of classrooms or localities differentiated along ethnic, cultural or religious lines. Taking note of Jøsok Gansmo's (2003) research on Norwegian schools and their response to "state feminism", smaller scale initiatives might reach girls by connecting them more deeply with their communities and making the technology 
real-world relevant. Indeed, it might be argued, those innovative but disobedient schools identified by Jøsok Gansmo (2003) as demonstrating the best possible response to the problem of girls and technology were in fact operating small-scale initiatives within the context of a broader framework of "state feminism." The fact that they did not have intervention strategies specifically geared towards gender equity should not be viewed as a weakness. Their greatest strength, after all, is their ability to use technology to include all students, regardless of gender, ethnicity, religious beliefs or physical or mental ability. At the risk of labouring this point, it appears that particular Norwegian schools, whilst taking advantage of top-down initiatives to boost their technological resources, nevertheless chose to hoist flags of inclusiveness rather than division, and that their students and communities benefited as a result.

As demonstrated by the success of British programs CC4G and ITBeat, industry-based initiatives have the potential for widespread penetration. Whilst it is perhaps still too early to tell if that penetration will reach deeply enough to effect much needed change, the approach advocated by programs such as CC4G and ITBeat, in which the person rather than the technology becomes the point of departure, is one that satisfies many calls in the literature for technology studies that are personal and real-world relevant. Whilst not as widely cited as might be expected, the freedom from bureaucratic constraints that industry-based programs appear to enjoy has nevertheless been seen by some researchers as important to the success of smaller scale intervention strategies. Such freedom promotes flexibility, adaptation, innovation, collaboration and rapid response.

Voluntary sector programs identified in this review suggest several things: that young people themselves see the socialisation of technology as immensely important; that girls and women reject "artificial" methods of recruitment into technology circles; that girls and women value technology for what it can do to advance their interests and the interests of their communities; and that the learning context or environment must incorporate the personal as well as the technical. They also suggest that even if all these issues are addressed in the learning phase, it will count for little unless cultural changes can be effected in the workplace. The Women's Electronic Village Hall (WEVH) project in Manchester, England is particularly instructive in its approach to tackling gender technology issues and enabling women to see the issue in terms of lack of suitable information rather than lack of ability on their behalf.

Whilst WEVH (now merged with Train 2000 http://www.wevh.org.uk/) was established as a women only training centre, it is interesting to note that other non-gender specific initiatives established at community levels have led de facto to greater participation of women in ICT studies and usage. Whilst it has been suggested that underlying reasons are more complex than might be suggested by gender-based arguments, it nonetheless appears that the predominance of female Community Support Workers involved with the Ardmore Network in the Scottish Hebrides was a significant factor in that program attracting many more females than males. There were, of course, other contributing factors, such as unequal or no access to computers in the home, previous experiences with technology, levels of comfort and security associated with the learning environment and occupational or outside interests. However, the overarching conclusion that must be reached is that more females than males were attracted to courses run through the Ardmore Network because the Network more adequately met the needs and interests of women.

Specifically addressing the needs of female learners also appears to have been responsible for the Amsterdam Westerpark Computers and the Internet initiative attracting almost three times as many women as men, even though that program was, like the Ardmore Network initiative, aimed at everyone in the community. If references to these projects and the WEVH initiative appear out of place in a review of strategies aimed at attracting high school girls to ICT because they happen to attract a higher proportion of mature age women than girls, their relevance should be understood in terms of what they say about the need for ICT studies and careers to meet the needs of female learners and workers. In both instances, women were provided with or made their own an 
environment in which they felt comfortable and secure. That the Scottish initiative was more successful than its Dutch counterpart in making women competent and enthusiastic ICT users had much more to do with its ability to build networks of local experts and informal learners than the technical prowess of instructors involved in the program. In other words, the success of the Scottish program and the relative failure of the Dutch initiative appear to lie in the first program's person-centred approach and the priority given by the second program to technology rather than people.

\section{Conclusions}

This review of strategies aimed at improving female participation in ICT studies and careers suggests three fundamental areas for attention: infrastructure, teacher training/attitudes, and the role of community. In Australia, the Federal Government's Digital Education Revolution (DER) promises to address issues of infrastructure and teacher training in the use of ICT through a oneto-one computer to student ratio for secondary school students between years nine and twelve and through professional development for teachers. This initiative, which also provides for high-speed broadband connection to Australian schools, should see increased incorporation of ICT into pedagogical practices. Whilst the resources flowing from the DER are to be welcomed and applauded, they do not necessarily address the longer-term and equally critical requirement to foster progressive attitudes among teachers and rising school leaderships where the question of ICT and its interactions with gender, race and socio-economic status are concerned. The example provided by Norwegian schools in which ICT has been used as an agent of inclusion suggests that intervention strategies designed to meet the needs of students as members of a community may be more effective than strategies that begin with a specific gender focus.

\section{References}

Anderson, N. (2003). Making the link: Three successful university, industry and community collaborations around ICT development. Higher Education without Borders - Sustainable Development in Education, Khon Kaen, Thailand, 44-51. Retrieved 15 January, 2009 from http://eprints.jcu.edu.au/834/

Association of Women Educators (2006). AWE Policy: Girls and information and communication technologies. Retrieved 10 October, 2009 from http://www.awe.asn.au/documents/AWEGirlsICTs.doc

Barrios, J. (2003, 28 June). Summer camp steers teen girls toward computer science field. Austin American-Statesman. Retrieved 10 October, 2009 from http://www.utsystem.edu/News/Clips/DailyClips/2003/0622-0628/UTAustin-AAS-SummerCamp062803.pdf

Bennett, D., Hsi, S., Lake, C., \& Moore, K. (2000). Tech savvy: Educating girls in the new computer age, AAUW Educational Foundation Commission on Technology, Gender and Teacher Education, Washington: American Association of University Women Educational Foundation. Retrieved 10 October, 2009 from http://www.aauw.org/research/upload/TechSavvy.pdf

Butler, D. (2000). Gender, girls, and computer technology: What's the status now? Clearing House, 73(4), 225-229.

Christie, R., \& Healy, J. (2004). How to get them in with food, charm and goodies - the "Go For IT gURL!" strategy. In S. Spencer (Ed.), Proceedings of the 2004 Australian Women in IT ConferenceMaking a Difference (AusWIT 2004) (pp. 35-40), Adelaide.

Clayton, D., \& Lynch, T. (2002). Ten years of strategies to increase participation of women in computing programs, The Central Queensland University experience: 1999-2001. SIGCSE Bulletin, 34(2), 89-93.

Courtney, L., Timms, C., Lankshear, C., \& Anderson, N. (2005). Establishing pathways for girls in ICT: The search for strategies to achieve balance in Queensland. Journal of the Association of Women Educators, 14(3), 14-19. 
Craig, A. (2009). Intervention programmes to recruit female computing students: Why do the programme champions do it? In M. Hamilton \& T. Clear (Eds.), Proceedings of the Eleventh Australasian Computing Education Conference, Wellington, New Zealand. Retrieved 15 November, 2009 from http://crpit.com/confpapers/CRPITV95Craig.pdf

Department of Innovation, Industry and Regional Development. (2009). Attitudes to ICT careers and study among 14 to 19 year old Victorians. Retrieved from http://www.mmv.vic.gov.au/Assets/2337/1/StudentsAttitudesTowardsICT09.pdf

Falkenberg Lund, K., \& Spanner Witzke, A. S. (2006). Innovative reinforcement of computer science to girls. Proceedings of the $10^{\text {th }}$ Australian Women in IT Conference (AusWIT 2006): partICipaTion one year on. Retrieved 5 September, 2009 from http://www.ozwit.org/version three/files/Final\%20papers/Falkenberg\%20lund.pdf

Faulkner, W., \& Kkeif, T. (2003). Rural community resource centres: A case of "de facto" women's inclusion in the information society. Deliverable D03/Appendix 2.8 of IST-2000-26329 SIGIS Project. Retrieved 5 September, 2009 from http://www.rcss.ed.ac.uk/sigis/public/displaydoc/full/D03 2.08 UEDIN2

Faulkner, W., \& Stewart, J. (2003). National ICT training for teachers: A case of "gender blindness"? Deliverable D03/Volume 1 of IST-2000-26329 SIGIS Project. Retrieved 5 September, 2009 from http://www.rcss.ed.ac.uk/sigis/public/documents/SIGIS_D03_2.09_UEDIN3.pdf

Fisher, J., Lang, C., Craig, A., Forgasz, H., \& Lazarenko, K. (2007). Report on the effectiveness of "girls only" computer clubs in Australia. Retrieved 24 September, 2009 from http://www.vicictforwomen.com.au/resources/documents/Report_Girls_only_Computer_Clubs_071.pdf

Graham, S., \& Latulipe, C. (2003). CS girls rock: Sparking interest in computer science and debunking the stereotypes. ACM SIGCSE Bulletin, 35(1), 322-326.

Gras-Velazquez, A., Joyce, A., \& Debry, M. (2009). Women and ICT: Why are girls still not attracted to ICT studies and careers? White paper, Insight observatory for new technologies and education, European SchoolNet. Retrieved 5 November, 2009 from http://insight.eun.org/ww/en/pub/insight/misc/specialreports/eun_white_paper_women_it.htm

Heemskerk, I., Brink, A., Volman, M., \& ten Dam, G. (2005). Inclusiveness and ICT in education: A focus on gender, ethnicity and social class. Journal of Computer Assisted Learning, 21, 1-16.

Heemskerk, I., ten Dam, G., Volman, M., \& Admiraal, W. (2009). Gender inclusiveness in educational technology and learning experiences of girls and boys. Journal of Research on Technology in Education, 41(3), 253-276.

Higher Education Council (HEC), Department of Employment, Education and Training (DEET) \& National Board of Employment, Education and Training (1990). A fair chance for all: National Institutional Planning for Equity in Higher Education: A discussion paper. Australian Government Publishing Service, Canberra, Australia. Retrieved 17 March, 2010 from http://www.dest.gov.au/sectors/training_skills/publications_resources/indexes/documents/90 06 pdf.h $\underline{\mathrm{tm}}$

How to diversify the geek pool. (2000). Training, 37(6), 32.

Jenson, J., de Castell, S., \& Bryson, M. (2003). "Girl Talk": Gender, equity, and identity discourses in a school-based computer culture. Women's Studies International Forum, 26(6), 561-573. Retrieved 5 September, 2009 from http://www.shecan.com/

Jøsok Gansmo, H. (2003). Limits of state feminism: Chaotic translations of the "girls and computing" problem. Deliverable D03/Volume 1 of the IST-2000-26329 SIGIS Project. Retrieved 5 September, 2009 from http://www.rcss.ed.ac.uk/sigis/public/documents/SIGIS_D03 2.02_NTNU2.pdf

Lang, C., Fisher, J., \& Craig, A. (2007). Digital divas: Computer clubs for girls trial. Brentwood Secondary College, Swinburne University of Technology Women in ICT Group and Victorian ICT for Women Network. Retrieved 5 September, 2009 from 
http://www.swinburne.edu.au/ict/wict/documents/Report\%20on\%20Brentwood\%20Computer\%20Clu b\%20Trial.pdf

Lanzer, F. (2009). Attracting girls to engineering \& technology: Reach them before they're turned off. Proceedings of the 2009 Mid-Atlantic Section Conference of the American Society for Engineering Education, Baltimore, MD. Retrieved 5 September, 2009 from http://ola3.aacc.edu/fplanzer/documents/Attracting\%20Girls\%20to\%20Technology\%20Reach\%20The $\underline{\mathrm{m} \% 20 \text { Before } \% 20 \text { Turnoff.doc }}$

Margolis, J., Jellison Holme, J., Estrella, R., Goode, J., Nao, K., \& Stumme, S. (2003). The computer science pipeline in urban high schools: Access to what? For whom? IEEE Technology and Society Magazine, 22(3), 12-19.

McCullough, C. (2002). Attracting under-represented groups to engineering and computer science. Proceedings of the American Society of Engineering Education Southeastern Section Conference (pp. 111), Gainesville, Florida. Retrieved 5 September, 2009 from http://155.225.14.146/aseese/proceedings/ASEE2002/P2002046COEETMCC.pdf

Nordli, H. (2003). The gathering. Computer parties as means for gender inclusion. Deliverable D04/Appendix 2.1 of IST-2000-26329 SIGIS Project. Retrieved 13 September, 2009 from http://www.rcss.ed.ac.uk/sigis/public/documents/SIGIS_D04_2.01_NTNU1.pdf

Philippine Legislators' Committee on Population and Development Foundation, Inc., and WomensHub (Philippines) (2003). Gender and ICT in the Philippines: A proposed policy framework, 1-13. Retrieved 20 November, 2009 from http://old.apc.org/english/capacity/policy/mmtk_gender_ictpol_philippines.pdf

Pitt, L. (2003). Don't leave IT to the boys! Deliverable D05/Appendix 2.1 of IST-2000-26329 SIGIS Project. Retrieved 5 September, 2009 from http://www.rcss.ed.ac.uk/sigis/public/documents/SIGIS_D05 2.01_UEDIN1.pdf

Rees, T. (2001). Mainstreaming gender equality in science in the European Union: The 'ETAN' Report, Gender and Education, 13(3), 243-260.

Rommes, E. (2003). I don't know how to fit it into my life. Courses computers and the Internet for "everybody" in Amsterdam. Deliverable D03/ Appendix 2.4 of IST-2000-26329 SIGIS Project, Retrieved 5 September, 2009 from http://www.rcss.ed.ac.uk/sigis/public/displaydoc/full/D03 2.04_TWENTE1

Scott, V.A. (1998). Why are girls under represented? Ten years on. Australian Educational Computing, 11(1), 17-21.

Schoutendorp, M., van den Steenhoven, J., \& Lenos. (2002). Monitor Digitale Trapvelden 2002, stand van zaken. Amsterdam, Netwerk Digitale Trapvelden.

Shah, C., Burke, G., \& North, S. (2008). University ICT graduates for ICT occupations in Victoria 2008 to 2022. Report prepared for Multimedia Victoria, Department of Innovation, Industry and Regional Development by Monash University - ACER Centre for the Economics of Education and Training. Retrieved 2 March, 2010 from http://www.mmv.vic.gov.au/Assets/2114/1/University_IT_graduates for_ICT_occupations in_Victori a 2008 to $2022 . p d f$

Steele, S. (2008). CC4G 2007/2008 evaluation report. Retrieved from http://www.eskills.com/public/File/CC4G/Celebration/CC4G_DCSF_EvaluationReport_2008.pdf

Teague, G. J., \& Clarke, V. A. (1993). Attracting women to tertiary computing courses: Two programs directed at secondary level. ACM SIGCSE Bulletin, 25(1), 208-212.

Thomson, R. (2007). IT clubs for girls pave way to parity. Computer Weekly, 134.

Volman, M., van Eck, E., Heemskerk, I., \& Kuiper, E. (2005). New technologies, new differences. Gender and ethnic differences in pupils' use of ICT in primary and secondary education. Computers \& Education, 45(1), 35-55. 
Walker, M. (2005). Innovative new media training and its effects on women's lives. Proceedings of the $3^{\text {rd }}$ European Symposium on Gender \& ICT “Working for Change”. Retrieved 5 September, 2009 from http://ict.open.ac.uk/gender/2005/papers/index.html

Wigal, C. M., Alp, N., McCullough, C., Smullen, S., \& Winters, K. (2002). ACES: Introducing girls to and building interest in engineering and computer science careers. Proceedings of the $32^{\text {nd }}$ ASEE/IEEE Frontiers in Education Conference (F1C/8-F1C13), Boston, MA. Retrieved 10 November, 2009 from http://fie-conference.org/fie2002/papers/1221.pdf

\section{Biographies}

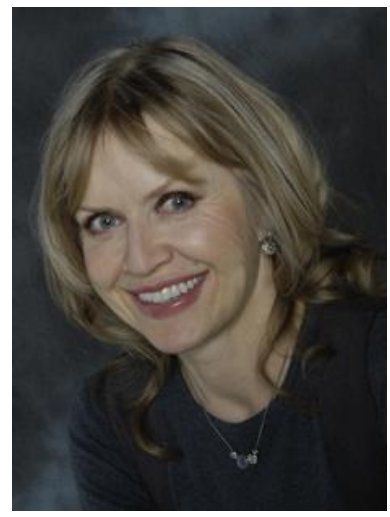

Dr Iwona Miliszewska is Associate Professor in computer science at Victoria University in Melbourne, Australia. She has led and participated in research projects involving transnational education, effective teaching methods, and females in ICT, and has published in these areas. In 2008/2009 Iwona led a research project investigating the perceptions of ICT studies and careers among female secondary school students from low socioeconomic backgrounds.

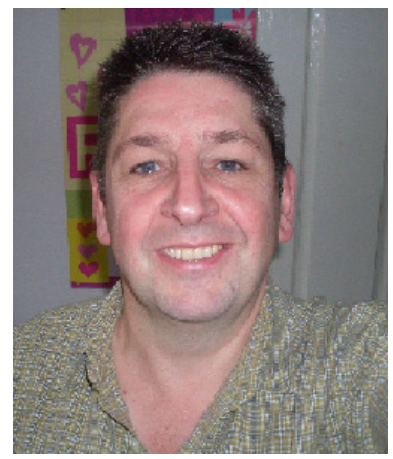

Aidan Moore is a PhD candidate in the Faculty of Arts, Education and Human Development at Victoria University, Melbourne. He also works part-time as a Research Assistant at the Centre for Innovation in Learning and Teaching at Victoria University. Aidan has been involved in several research projects related to the issues of higher education, including transnational education, gender equity, and student use of technology. 